\title{
Flow Hydraulic Investigation of the Wastewater on the Soil and Magnetic Field Effects in This Field
}

\author{
Hamid Raeisi Vanani ${ }^{1}$, Ali Reza Soltani Toudeshki ${ }^{1}$, Mohammad Shayannejad ${ }^{1}$, \\ Kaveh Ostad-Ali-Askari²*, Saeid Eslamian ${ }^{1}$, Mahboubeh Amoushahi-Khouzani ${ }^{3}$, \\ ${\text { Maryam Marani-Barzani }{ }^{4} \text {, Masoud Kazemi }}^{5}$ \\ ${ }^{I}$ Water Engineering Department, Isfahan University of Technology, Isfahan, Iran. \\ ${ }^{2 *}$ Department of Civil Engineering, Isfahan (Khorasgan) Branch, Islamic Azad University, Isfahan, \\ Iran. \\ ${ }^{3}$ Water Engineering Department, Science and Research Branch, Islamic Azad University, Tehran, \\ Iran. \\ ${ }^{4}$ Department of Geography, University of Malaya (UM), 50603 Kuala Lumpur, Malaysia. \\ ${ }^{5}$ Civil Engineering Department, Najafabad Branch, Islamic Azad University, Najafabad, Iran.
}

*Corresponding Author: Kaveh Ostad-Ali-Askari, Department of Civil Engineering, Isfahan (Khorasgan) Branch, Islamic Azad University, Isfahan, Iran.Email: Koa.askari@khuisf.ac.ir

\begin{abstract}
The effects of irrigation with treated wastewater on soil chemical and physical properties have been studied in many researches, but a few studies have done about waste water flow on the soil surface. In this study flow hydraulic of wastewater on soil surface was investigated and magnetic field effects on it was also studied. This research was done in the field with furrows (length of $42 \mathrm{~m}$, width of $60 \mathrm{~cm}$, depth of $25 \mathrm{~cm}$ and slope of $0.1 \%$ ) in Isfahan University of Technology and were used three water quality treatments consists of fresh water $(F W)$, wastewater $(W W)$ and magnetized wastewater $(M W)$. Magnetic field was created by three magnets with constant magnetic field intensity of 10mili-Tesla for each one. Basic differences between three water treatments were in biological parameters (Chemical oxygen demand (COD), Total-coli form) and total suspended solids (TSS). The Collected data were included of advance and recession time, inflow and outflow rates with four replications and five irrigation events for each treatment (overall 60 practices), in a randomized complete block design. The inflow rate for furrows was determined 0.8 lit/sec. The results showed magnetic field have not a considerable effect on the physical and chemical characteristics of the wastewater, though it changes oxygen demand and especially total coli forms. Also no significant difference was observed between the effects of water quality treatments on water infiltration characteristics, consist of basic infiltration rate $\left(f_{o}\right)$ and mean infiltration rate in two 30 minutes' time intervals (0-30 and 30-60 minutes), but in mean infiltration rate in 0-30 interval, mean relative changes for the $W W$ and $M W$ were about twice of the $F W$. Mean infiltration rate of the $F W$ has also less reduction than $W W$ and $M W$ in these intervals. However, scrutinizing of parameters variations in charts showed that $W W$ and $M W$ treatments relation to $F W$ ones created more changes in downtrend of " $f_{o}$ " during irrigation season and magnetic field effect was inconsiderable. The " $f_{o}$ " in $W W$ and $M W$ was more than $F W$ mostly. It was found that magnetic field causes increasing of the " $f_{o}$ " in $M W$ related to $W W$. Similar results also were found in two time intervals of infiltration process. Also excluding depletion time phase, evaluated time parameters, including advance time to furrow end, time to reach the " $f_{o}$ " and recession duration had not difference significantly influenced by water quality treatments, but values of advance time and time to reach the " $f_{o}$ " for $W W$ and $M W$ than FW were higher mostly. According to regressions equation between water quality parameters and flow hydraulic parameters, were found a negative correlation between " $f_{o}$ ", mean infiltration rate for 0-30min and 30-60min ranges and advance time with TSS and irrigation number; and a positive correlation between these parameters with COD; also a negative correlation between time to reach the " $f_{o}$ " and depletion time with $C O D$; and a positive correlation between these parameters with TSS and irrigation number. In parameter of recession duration, positive correlations are with irrigation number and $C O D$; and negative correlation is with TSS.
\end{abstract}

Keywords: Wastewater, Soil, Flow hydraulic, Furrow irrigation, Infiltration, advance and recession time 


\section{INTRODUCTION}

The reuse of treated wastewater in agriculture can be a sustainable solution to face water scarcity [1]. Irrigation with wastewater may have implications at two different levels: alter the physicochemical and microbiological properties of the soil and/or introduce and contribute to the accumulation of chemical and biological contaminants in soil. The first may affect soil productivity and fertility; the second may pose serious risks to the human and environmental health. Thus simultaneously, affordable technological solutions with minimal environmental impacts must be developed in order to assure wastewater treatment processes compatible with sustainable uses [2].Wastewater irrigation can be a very attractive proposition with benefits in the form of water conservation, nutrient recycling, surface and ground water pollution prevention, particularly for arid and semi-arid regions if used with proper and adequate management plans in place. For example, whenever and wherever wastewater irrigation is adopted, it is imperative that a regular monitoring of soil physical and chemical properties be done routinely in order to maintain the structural integrity of the already salt affected soils. Also some nutrients, particularly $\mathrm{N}$, although is essential for plant growth, can often be a limiting factor [3]. Herbaceous crops irrigated with wastewater can produce appreciable biomass and energy yields. This is also an environmentally and economically sound way of wastewater disposal [4]. With treated sewage irrigation, a slight increase in the organic content of the soil was observed [5].Saturated hydraulic conductivity of loam soil reduced with municipal wastewater. This reduction was more remarkable in the clay soil. Simulation of both ponded and sprinkler irrigation with municipal wastewater resulted in reduced infiltration and increased surface ponding condition compared to the application of fresh water [6-9].Irrigation with treated wastewater has been reported to induce low to moderate hydrophobicity in soils of different texture with or without vegetation cover [10-12].Studies have demonstrated that wastewater irrigation may decrease soil hydraulic conductivity and infiltration rate. Plots irrigated with highlysodic and alkaline industrial wastewater showed important structural damages, especially in the subsurface horizon where the soil pore network collapsed dramatically, resulting in a compact impermeable layer and also $\mathrm{pH}$ increase in the topsoil. Inadequate wastewater quality is likely to cause deep and irreversible damages to irrigated soils and resulting decrease of the yield[13-16].

Effects of irrigation with wastewater on soil chemical and physical properties have been investigated in many researches. However, few studies have done about wastewater flow on the soil surface [1724].Thus in this study flow hydraulic of treated wastewater in furrow irrigation was studied by parameters consists of infiltration and advance, storage, depletion and recession phases and fresh water was used as control. Magnetic field effects were also investigated on flow hydraulic of treated wastewater by magnetized wastewater [25-34].

\section{Materials ANd Methods}

\subsection{Experimental Site}

In order to achieve research purposes, three water quality treatments were selected included by fresh water (FW), wastewater (WW) and magnetized wastewater (MW). WW was effluent of treatment plant in Isfahan University of Technology. This plant has two lagoons of aeration (by some blowers) and stabilization (Fig. 1). FW was also supplied from piped water.
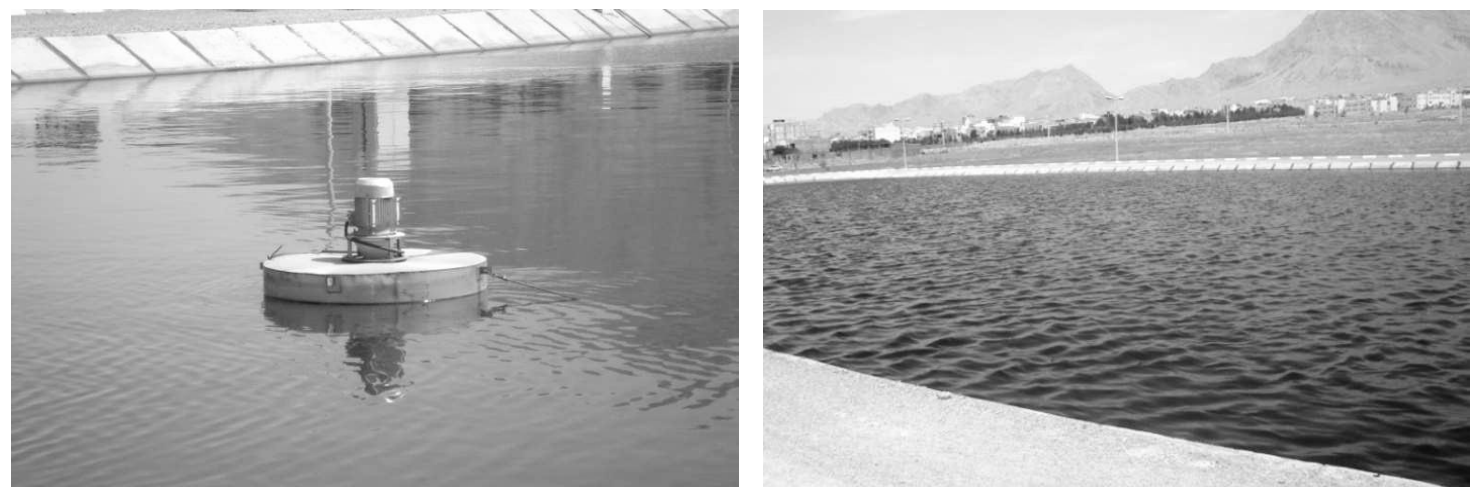

Fig1. Aeration and stabilization lagoons (left to right respectively)

Chah-Anari experimental field was also elected at the University of Technology, as well as its soil characteristics are presented in Table 1. 
Table1. Soil properties of the experimental field in two layers

\begin{tabular}{|c|c|c|c|c|c|c|}
\hline \multirow[b]{2}{*}{$\begin{array}{l}\text { Depth } \\
\mathrm{cm}\end{array}$} & \multicolumn{3}{|c|}{ Particle-size distribution } & \multirow[b]{2}{*}{$\begin{array}{c}\text { Textural class } \\
\text { (USDA) }\end{array}$} & \multirow{2}{*}{$\begin{array}{c}\text { Bulk } \\
\text { density } \\
\text { gr.cm }{ }^{-3}\end{array}$} & \multirow{2}{*}{$\begin{array}{c}\text { Initial } \\
\text { volumetric } \\
\text { moisture } \\
\%\end{array}$} \\
\hline & $\begin{array}{c}\text { Sand } \\
\% \\
\end{array}$ & $\begin{array}{c}\text { Silt } \\
\% \\
\end{array}$ & $\begin{array}{c}\text { Clay } \\
\% \\
\end{array}$ & & & \\
\hline $0-15$ & 50.4 & 21.8 & 27.8 & Sandy clay loam & $1.45-1.73$ & 2.94 \\
\hline $15-40$ & 52.3 & 20.3 & 27.4 & Sandy clay loam & $1.56-1.79$ & 2.87 \\
\hline
\end{tabular}

According to Table 1, soil texture is light.

\subsection{Field Preparing}

To field preparing the operations of plowing, disking and initial leveling was performed on it. After smoothing and supplementary leveling, furrows with a length of $42 \mathrm{~m}$, width of $60 \mathrm{~cm}$ and depth of $25 \mathrm{~cm}$ were created by furrower set. Then furrows slope was determined by surveying separately. Average longitudinal and latitudinal slope werecalculated $0.1 \%$ for furrows.

\subsection{Experimental instruments}

The water transmission system into the furrows was consists of FW and WW tanks, a Stabilization tank (by float valves) and the gated pipe. Two tanks of six and ten cubic meters were used separately for FW and WW supply at upstream end of the furrow respectively. The inflow rate for furrows was determined 0.8 lit/sec using the furrow slope and maximum non-erosive stream [35-43] and according to outflow rate from stabilization tank. To create of mentioned inflow rate, opening value of each gate on gated pipe was determined by graded container and timer and gate was opened the same amount in each practice [44-50]. WSC flumes were used to measure of the inflow and out flow in furrow. Flumes were installed perfectly horizontal and with a manner that was prevented from leakage current in vicinity and the free flow was also established (Fig. 2).

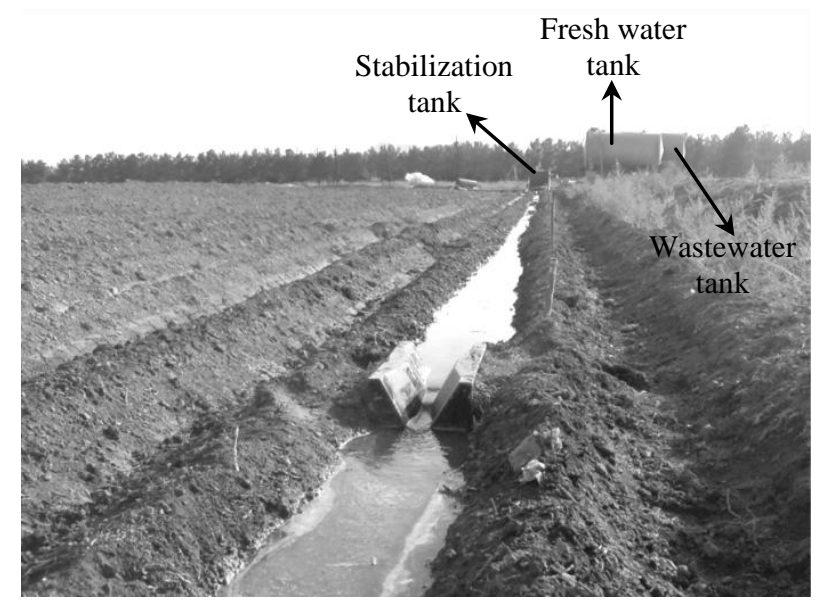

Fig2. Three tanks and flume used in research (view from furrow end)

The MW treatment was also created using three magnets with constant magnetic field intensity (10mili-Tesla for each one). These magnets were installed on pipe in near of outlet gates [51-58].

\subsection{Statistical Design And Experiment Implementation}

The used experimental design in this research was randomized complete block with three treatments (FW, WW and $\mathrm{MW}$ ) and four replications and five irrigation practices in each furrow. To implement the research, the four experimental blocks were applied in the field. Each block had one main and two lateral furrows for any of water treatments (overall three main and six lateral furrows). To apply the actual conditions in the field, two lateral furrows were considered for each main ones and tests were done in the main furrow. 60 furrow irrigations were evaluated in this study with 4 days' irrigation intervals (20 irrigation practices with FW treatment firstly and then 20 irrigations with WW and 20 irrigations with MW ones).It is important to note that MW irrigation was done with same quality of WW but in form of magnetized in each practice. The experimental farm had no cultivation and irrigation was not also done in it previously. Furrows length was divided with three meter intervals from location of inlet flume installation toward downstream (15 stations in each furrow).Irrigation 
practice was begun with transfer of water to furrow and parameters were measured such as advance and recession time and inflow and outflow rate in each experiment. Water flow into the furrow continued until outflow rate was constant. Recession times were also recorded at various stations after cut off time immediately.

\subsection{Determining of Infiltration Parameters}

To obtain the infiltration equation was used from the inflow-outflow method. In this method after the advance stage completion, infiltration rate is equal to the inflow and outflow rate difference at a specified time in furrow length with assumption of small changes in surface storage. Surface storage changes can be neglected in furrows with some conditions. For example, in this paper according to irrigation time, advance time and furrow length from changes in surface storage rate were neglected. Thus infiltration rate and cumulative infiltration equations were determined by Eqs. 1, 2:

$$
I=\frac{Q_{\text {in }}-Q_{\text {out }}-R_{s s}}{L} \& R_{s s} \approx 0, Z=\int I d t
$$

Where $Q_{\text {in }}=$ inflow rate; $Q_{\text {out }}=$ outflow rate; $R_{s s}=$ surface storage rate; $L=$ furrow length; $I_{\text {ave }}=$ average infiltration rate in furrow length; and $Z=$ cumulative infiltration equation. " $I$ "is for when the inflow and outflow rates are " $Q_{i n}$ " and " $Q_{\text {out }}$ " values respectively. Finally, parameters of Kostiakov infiltration rate equation $\left(I=k \cdot t^{a}\right)$ were calculated by various values of " $I$ " and times related to them. In this paper average infiltration in three time intervals consists of 0-30, 30-60 and 60-90 minutes was calculated for each water treatment from the following equation:

$$
I_{\text {ave }}=\frac{Z_{2}-Z_{1}}{t_{2}-t_{1}}
$$

Where $I_{\text {ave }}=$ average infiltration in time interval of " $t_{2}-t_{1}$ "; $Z_{2}, Z_{1}=$ cumulative infiltration to " $t_{2}$ " and " $t_{1}$ " times respectively (using Eq. 2).The soil basic infiltration rate $\left(f_{o}\right)$ was also calculated with Eq. 4:

$$
f_{o}=\frac{Q_{\text {in-const }}-Q_{\text {out-const }}}{L}
$$

Where $Q_{\text {in-const }}$ and $Q_{\text {out-const }}$ are fixed values of inflow and outflow rate in furrow irrigation practice.

\subsection{Water and Wastewater Quality Experiment}

Sampling is first step in identifying of the water and wastewater quality and decision for their management. In this study samples were indicative of water and wastewater quality of used supply in this paper. Samples were taken from the gates exit of the tube in the second, fourth and fifth irrigations. For FW treatment due to negligible changes in water quality, tests were done once in the irrigation season. Samples transfer to the laboratory was performed in a short time and at low temperatures (samples were near the pieces of ice). Sampling bottles were plastic and non-transparent. Standard used in determining experiments of water and wastewater quality were taken from "standard methods for the examination of water and wastewater" book.

\subsection{Statistical Analysis}

Data were analyzed using SPSS and Excel software. Data relative changes were used for analysis and evaluation. These relative changes were calculated as follows:

$$
P_{r}=\frac{P_{5}-P_{1}}{P_{1}}
$$

Where $P_{r}=$ relative change of " $P$ " parameter in fifth irrigation than first one; $P_{5}, P_{1}=$ measured parameter in the fifth and first irrigation respectively. The " $P_{r}$ "shows that " $P$ " parameter how much has changed after five irrigations.

\section{RESUlTS AND DISCUSSION}

\subsection{Water Quality Analysis}

Results of water quality experiments are presented in Table2. 
Flow Hydraulic Investigation of the Wastewater on the Soil and Magnetic Field Effects in This Field

Table2. Fresh Water, wastewater and magnetized wastewater quality used in the study

\begin{tabular}{|c|c|c|c|c|c|c|c|c|}
\hline \multirow{2}{*}{ Parameters } & \multirow{2}{*}{ Unit } & \multirow{2}{*}{ Fresh water } & \multicolumn{3}{|c|}{ Wastewater } & \multicolumn{3}{|c|}{ Magnetized wastewater } \\
\hline & & & Second & Fourth & Fifth & Second & Fourth & Fifth \\
\hline $\mathrm{Na}^{+}$ & $\mathrm{mmolL}^{-1}$ & 5.20 & 9.50 & - & 4.80 & 10.50 & - & 4.80 \\
\hline $\mathrm{K}^{+}$ & $\mathrm{mmolL}^{-1}$ & 0.06 & 0.90 & - & 0.30 & 0.90 & - & 0.30 \\
\hline $\mathrm{Ca}^{++}$ & mmolL $^{-1}$ & 2.30 & 2.25 & - & 3.10 & 2.35 & - & 3.20 \\
\hline $\mathrm{Mg}^{++}$ & $\mathrm{mmolL}^{-1}$ & 0.70 & 0.85 & - & 2.50 & 0.45 & - & 3.10 \\
\hline $\mathrm{HCO}_{3}^{-}$ & mmolL $^{-1}$ & 7.75 & 4.40 & - & 4.90 & 4.80 & - & 4.80 \\
\hline $\mathrm{CO}_{3}^{--}$ & $\mathrm{mmolL}^{-1}$ & 0.00 & 0.00 & - & 0.25 & 0.00 & - & 0.30 \\
\hline $\mathrm{SO}_{4}^{--}$ & $\mathrm{mmolL}^{-1}$ & 0.55 & 0.79 & - & 0.15 & 0.79 & - & 2.10 \\
\hline $\mathrm{Cl}^{-}$ & $\mathrm{mmolL}^{-1}$ & 6.25 & 10.63 & - & 10.60 & 10.63 & - & 8.10 \\
\hline SAR & $(\mathrm{mmol})^{0.5} \mathrm{~L}^{-0.5}$ & 4.25 & 7.63 & - & 2.87 & 8.87 & - & 2.70 \\
\hline $\mathrm{pH}$ & - & 7.55 & 8.26 & 7.26 & 8.01 & 8.30 & 7.56 & 7.79 \\
\hline $\mathrm{EC}$ & $\mathrm{dSm}^{-1}$ & 0.656 & 0.990 & 1.095 & 1.099 & 1.002 & 1.108 & 1.100 \\
\hline TSS & $\mathrm{mgL}^{-1}$ & 10 & 60 & 68 & 53 & 61 & 65 & 56 \\
\hline DO & $\mathrm{mgL}^{-1}$ & 6.8 & - & - & - & - & - & - \\
\hline COD & $\mathrm{mgL}^{-1}$ & 0 & 92 & 110 & 84 & 95 & 102 & 93 \\
\hline Total-coliform & $\operatorname{MPN}(100 c c)^{-1}$ & 0 & $23.3 \times 10^{4}$ & $6.9 \times 10^{4}$ & $17.6 \times 10^{4}$ & $35.6 \times 10^{4}$ & $10.5 \times 10^{4}$ & $2.0 \times 10^{4}$ \\
\hline
\end{tabular}

Note: second, fourth and fifth are irrigation numbers

According to Table 2, FW treatment is more acidic than WW and MW ones (in more cases).Electrical conductivity (EC) of $\mathrm{MW}$ is negligible more than WW and WW is more than FW too. Total suspended solids (TSS) of WW and MW are also more than five times compared to FW. It is important to say that basic differences between three water treatments are in biological parameters (Chemical oxygen demand (COD), Total-coli form).Results show that magnetic field has no significant effect on wastewater quality.

\subsection{Water Treatments Effects on Basic Infiltration Rate}

The values of $f_{o}$ were calculated by Eq. 4. These values are shown for different treatments and irrigation numbers in Fig. 3.
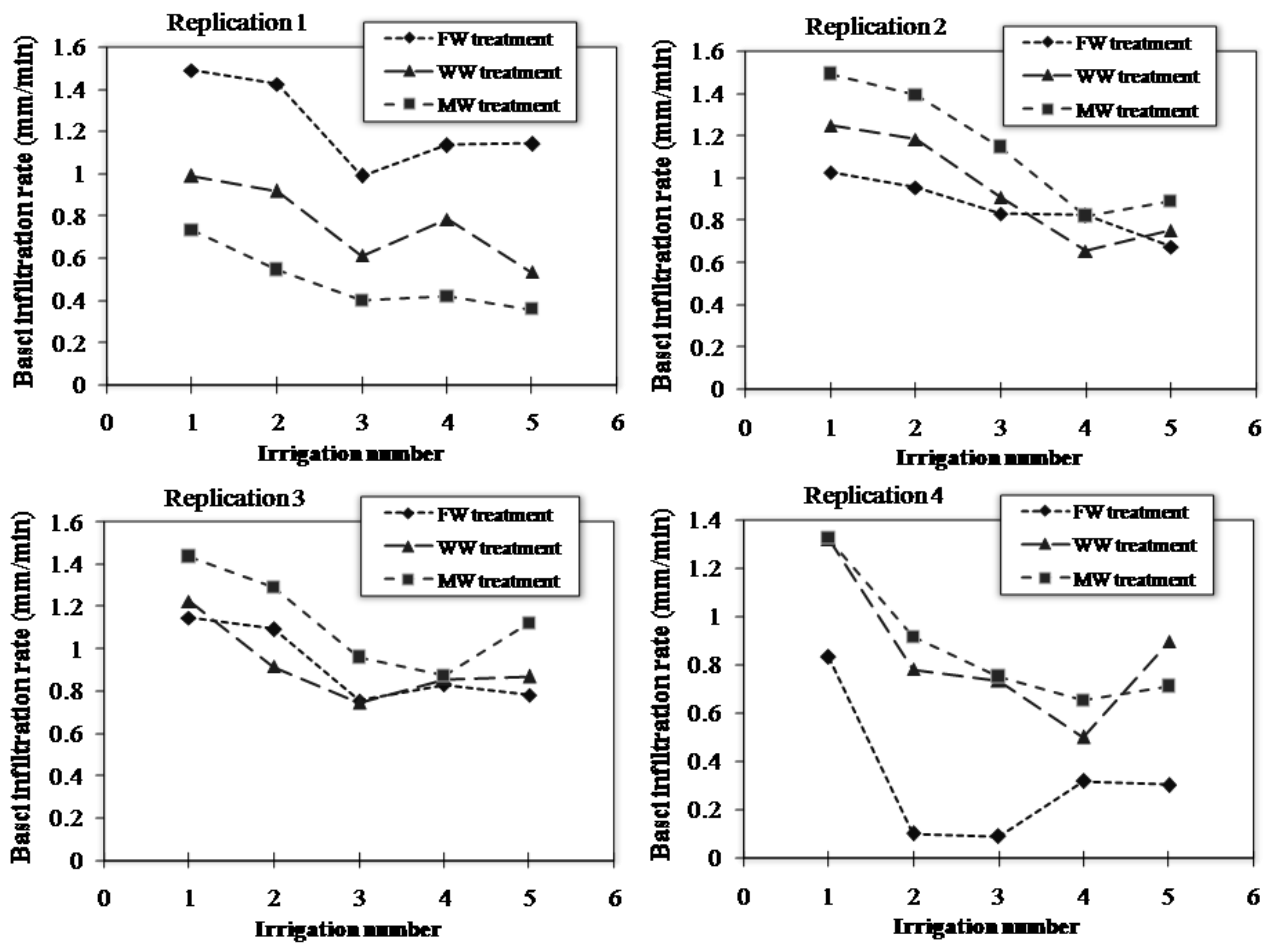

Fig3. Basic infiltration rate $\left(f_{o}\right)$ in different irrigation numbers

Note: Relative changes were calculated by Eq. 5

Parameter of " $f_{o}$ " has a downtrend for irrigation treatments during the irrigation numbers in Fig. 3. This result observes always in infiltration process that is caused by soil compaction with passage of 
time and decreasing of soil Matric potential. The " $f_{0}$ " for WW treatment is also with higher values than FW treatment in more cases (60\% of irrigation practices).In $70 \%$ of irrigations, " $f_{o}$ " values are also more for MW than FW in the specific irrigation numbers. It can be also found that magnetic field causes increasing of the " $f_{o}$ " in MW related to WW. Results show that downtrend of " $f_{o}$ " for WW and MW is with more intensity (slope) compared to FW that for WW is most (Fig. 3) in five irrigations. Further reduction of " $f_{o}$ " in WW is justifiable with soil pore clogging affected by suspended solids of wastewater. It also seems, the water quality effects on soil infiltration will be less important with the passage of irrigation season; and after soil stabilization in several irrigations (three irrigations in this study), the " $f_{o}$ " changes will not be too noticeable.

The regression equation was also determined by the multiple regression analysis between irrigation number, wastewater quality (TSS and COD because these parameters are basic differences between three water treatments in this paper)and " $f_{o}$ ". The resultant equation is as follows for " $f_{o}$ " of WW and MW in different irrigation numbers:

$$
f_{o}=2.185-0.042 T S S+0.017 C O D-0.131 N
$$

with a value for the coefficient of determination $R^{2}$ of 0.26 (that is not very strong), where $f_{o}=$ value of basic infiltration rate as $\mathrm{mm} / \mathrm{min} ; T S S=$ total suspended solids as $m g L^{-1} ; C O D=$ chemical oxygen demand as $m g L^{-1}$; and $N=1,2, \ldots$ that is irrigation number. According to Eq. 6the regression coefficients of TSS and $N$ are negative that shows the decreasing value of " $f_{o}$ " with increasing total suspended solids and irrigation number, but values of " $f_{o}$ " have a positive correlation with $C O D$.

Using analysis of change sources was found that treatments had no significant effect on " $f_{o}$ ". The method of least squares differences (LSD) also showed that mean values of relative changes for " $f_{o}$ " in FW, WW and MW treatments have no significant difference (Table 3). In this Table, whatever significant level is closer to $5 \%$ means that the difference data is near of $5 \%$ significance level and similarly for significance at $1 \%$ level. In Table 3 is also compared treatments difference together in terms of significant level.

Table3. Statistical analysis for soil basic infiltration rate

\begin{tabular}{|c|c|c|c|c|c|c|c|}
\hline \multirow{2}{*}{ Change source } & \multirow{2}{*}{\multicolumn{2}{|c|}{ Free degree Significant level }} & \multirow{2}{*}{\multicolumn{2}{|c|}{$\begin{array}{c}\text { Mean values of } \\
\text { Treatment relative changes }\end{array}$}} & \multicolumn{3}{|c|}{ Significant level } \\
\hline & & & & & $\mathrm{FW}$ & WW & MW \\
\hline Treatment & 2 & $94 \%$ & FW & $-0.331 \mathrm{a}$ & $100 \%$ & $94 \%$ & $67 \%$ \\
\hline Replication & 3 & $39 \%$ & WW & $-0.337 \mathrm{a}$ & $94 \%$ & $100 \%$ & $70 \%$ \\
\hline Experimental error & 6 & - & MW & $-0.363 a$ & $67 \%$ & $70 \%$ & $100 \%$ \\
\hline
\end{tabular}

\subsection{Mean Infiltration Rate in 0-30min and 30-60min Intervals}

Mean infiltration rate (using Eqs. 1-3) were used in three different intervals to changes investigate of infiltration equation (Kostiakov) parameters influenced by water treatments simultaneously. Mean infiltration rate values are presented for 0-30-minuteinterval in Fig. 4.

According to Fig. 4 mean infiltration rate in $0-30$ min interval for FW is more than WW and MW in more cases. This is probably due to more pollution loads in WW treatment create difficult for rapid WW and MW infiltration into the soil in early infiltration time. This parameter for WW is more compared with MW in $70 \%$ of irrigations. A downward trend can be also seen for mean infiltration rate during irrigation numbers.

The regression equation for mean infiltration rate in $0-30 \mathrm{~min}$ interval of $\mathrm{WW}$ and $\mathrm{MW}$ is as following:

$$
M I R_{0-30}=1.922-0.012 T S S+0.003 C O D-0.071 N
$$

with a value for the coefficient of determination $R^{2}$ of 0.05 (very poor), where $M I R_{0-30}=$ value mean infiltration rate for $0-30 \mathrm{~min}$ as $\mathrm{mm} / \mathrm{min} ; T S S, C O D$, and $N$ as before. As can be seen regression coefficients of TSS and $N$ are negative but for $C O D$ is positive.

Results did not show significant effect of treatments on mentioned parameter in range of $0-30 \mathrm{~min}$. 
Comparison of mean relative changes did not also get significant results (Table 4).But mean relative changes for the WW and MW is about twice of the FW. Mean infiltration rate of the FW has less reduction than WW and MW referring to Fig. 4 and Table. 4.
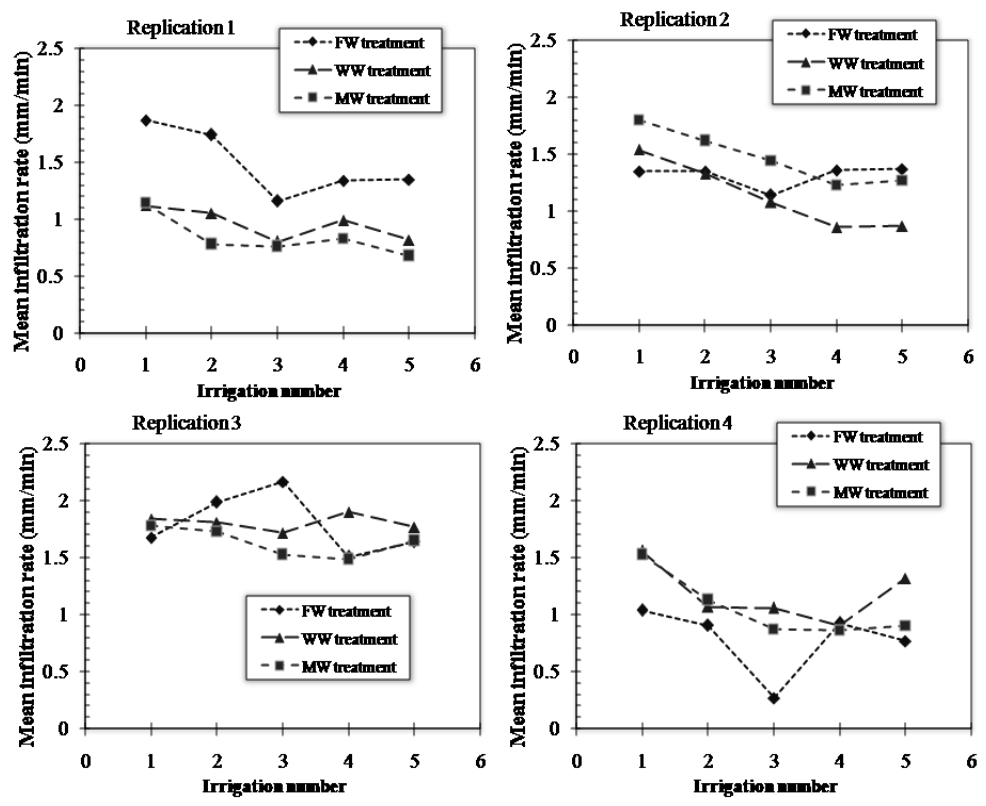

Fig4. Values of mean infiltration rate for 0-30min

Table4. Statistical analysis for mean infiltration rate in 0-30 min

\begin{tabular}{lcclcccc}
\hline \multirow{2}{*}{ Change source } & \multirow{2}{*}{ Free degree Significant level } & & \multicolumn{2}{c}{ Mean values of } & \multicolumn{3}{c}{ Significant level } \\
\cline { 5 - 8 } & & & Treatment relative changes & FW & WW & MW \\
\hline Treatment & 2 & $31 \%$ & FW & $-0.094 \mathrm{a}$ & $100 \%$ & $46 \%$ & $31 \%$ \\
Replication & 3 & $16 \%$ & WW & $-0.209 \mathrm{a}$ & $46 \%$ & $100 \%$ & $73 \%$ \\
Experimental error & 6 & - & MW & $-0.260 \mathrm{a}$ & $31 \%$ & $73 \%$ & $100 \%$ \\
\hline
\end{tabular}

Mean infiltration rate was following for 30-60min interval.

Mean infiltration rate for WW and MW treatments has more values in this range than FW ones $(65 \%$ of total irrigations) and FW treatment has also less reduction than other two treatments (Fig. 5).Magnetic field has caused increasing of mean infiltration rate in 30-60min interval for MW related to WW in more cases. Also results show that changes of mean infiltration rate for MW is similar to WW.
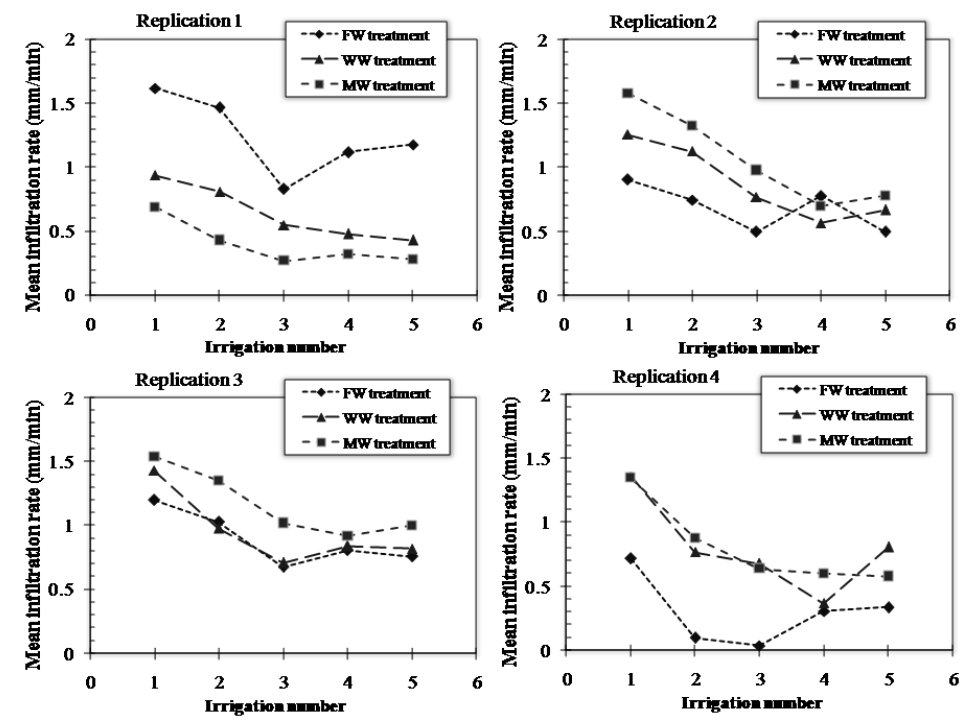

Fig5. Mean infiltration rate for 30-60min range

The regression equation for this parameter is Eq. 8 (for WW and MW treatments): 
$M I R_{30-60}=2.272-0.026 T S S+0.006 C O D-0.139 N$

with $R^{2}$ of 0.30 (stronger than $R^{2}$ for 0-30min interval), where $M I R_{30-60}=$ value mean infiltration rate for $30-60 \mathrm{~min}$ as $\mathrm{mm} / \mathrm{min}$;TSS,COD, and $N$ as before. Regression coefficients of wastewater qualities are more related to ones in 0-30min interval that shows the effect of wastewater quality becomes more tangible with over time.

Statistical comparison of the results shows no significant differences after five irrigations for treatments effects on mean infiltration rate in this range (Table 5). However, these results compared to 0-30min range show less significant level in comparison of treatments together. (i.e. being more significant in differences).

Table5. Statistical analysis for mean infiltration rate in 30-60 min

\begin{tabular}{lcclcccc}
\hline \multirow{2}{*}{ Change source } & \multirow{2}{*}{ Free degree Significant level } & & \multicolumn{2}{c}{ Mean values of } & \multicolumn{3}{c}{ Significant level } \\
\cline { 6 - 8 } & & & Treatment & relative changes & FW & WW & MW \\
\hline Treatment & 2 & $39 \%$ & FW & $-0.360 \mathrm{a}$ & $100 \%$ & $30 \%$ & $13 \%$ \\
Replication & 3 & $51 \%$ & WW & $-0.432 \mathrm{a}$ & $30 \%$ & $100 \%$ & $47 \%$ \\
Experimental error & 6 & - & MW & $-0.478 \mathrm{a}$ & $13 \%$ & $47 \%$ & $100 \%$ \\
\hline
\end{tabular}

\subsection{Treatments Effects on Advance Time}

Water reaching to the furrow end is presented for different replications in Fig. 7.From this parameter was used to compare the treatments effects on water advance speed on the soil.

There is a downtrend in advance times during irrigation numbers that is due to infiltration decreasing. Advance time for WW and MW is more than FW in 60\% practices and these results are due to high infiltration and roughness coefficient for WW and MW treatments (Fig. 6).
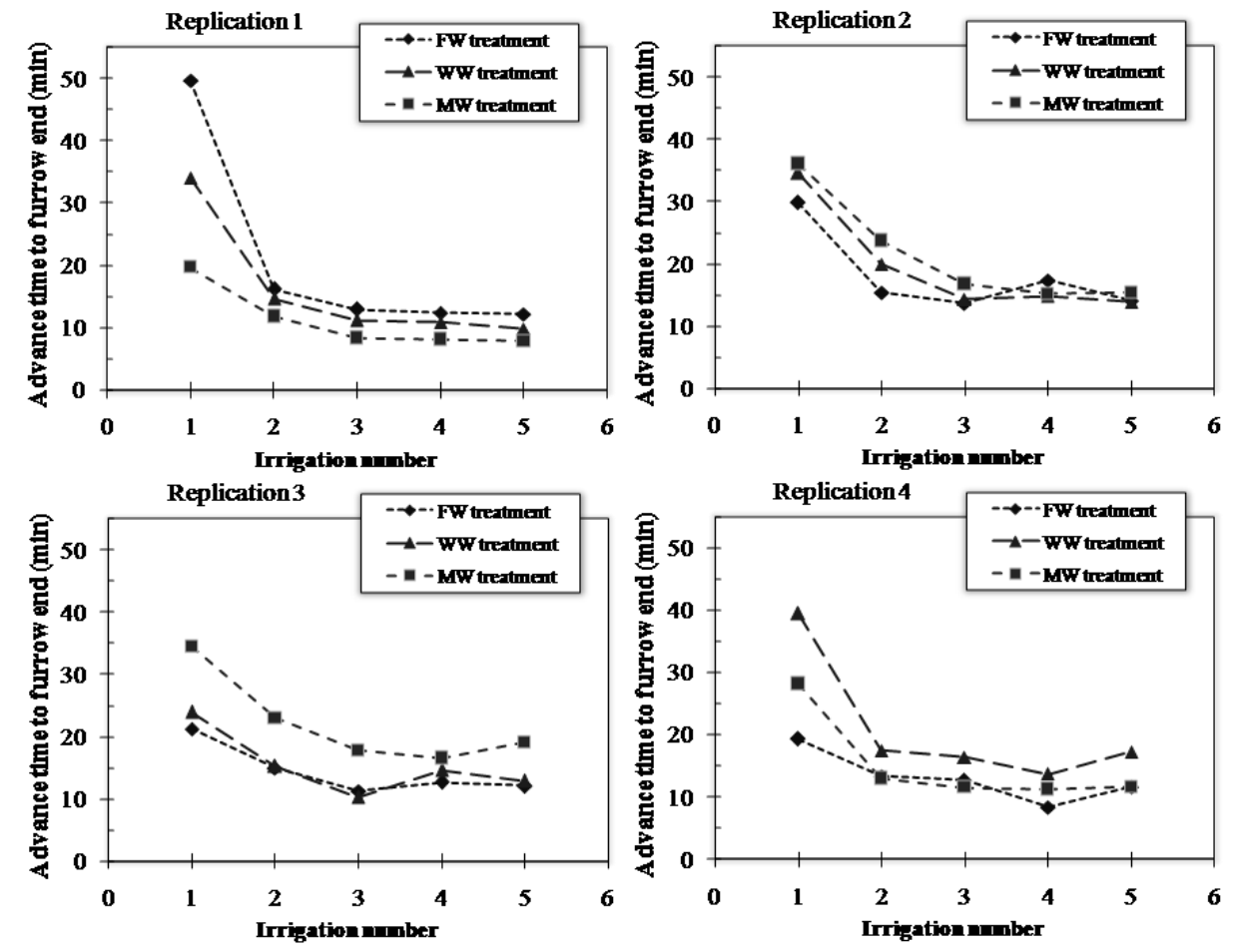

Fig6. Advance time parameter

The regression equation for this parameter is Eq. 9 (for WW and MW treatments):

$T_{a d v}=31.555-0.560 T S S+0.254 C O D-1.998 N$

with $R^{2}$ of 0.23 , where $T_{a d v}=$ advance time as $\min ; T S S, C O D$, and $N$ as before.

Advance time reduction for WW treatment is also more than the other treatments during the irrigation season. Magnetic field effect on advance times is impalpable and more differences are between FW 
and WW that Table 6 shows this result too.

Advance times of treatments are close to each other (Fig. 6) for this reason statistical analysis showed that relative changes have no significant difference (Table 6).

Table6. Statistical analysis for advance time of water front to furrow end

\begin{tabular}{|c|c|c|c|c|c|c|c|}
\hline \multirow{2}{*}{ Change source } & \multirow{2}{*}{\multicolumn{2}{|c|}{ Free degree Significant level }} & \multirow{2}{*}{ Treatment } & \multirow{2}{*}{$\begin{array}{l}\text { Mean values of } \\
\text { relative changes }\end{array}$} & \multicolumn{3}{|c|}{ Significant level } \\
\hline & & & & & FW & WW & MW \\
\hline Treatment & 2 & $55 \%$ & FW & $-0.527 \mathrm{a}$ & $100 \%$ & $30 \%$ & $62 \%$ \\
\hline Replication & 3 & $3 \%$ & WW & $-0.584 \mathrm{a}$ & $30 \%$ & $100 \%$ & $55 \%$ \\
\hline Experimental error & 6 & - & MW & $-0.552 \mathrm{a}$ & $62 \%$ & $55 \%$ & $100 \%$ \\
\hline
\end{tabular}

\subsection{Treatments Effects on Storage Stage}

Time that late to reach the " $f_{o}$ " after the run off beginning was analyzed as storage time in treatments, because time to reach the basic infiltration rate is equal with time for reaching the maximum surface storage. These times are as following graph:
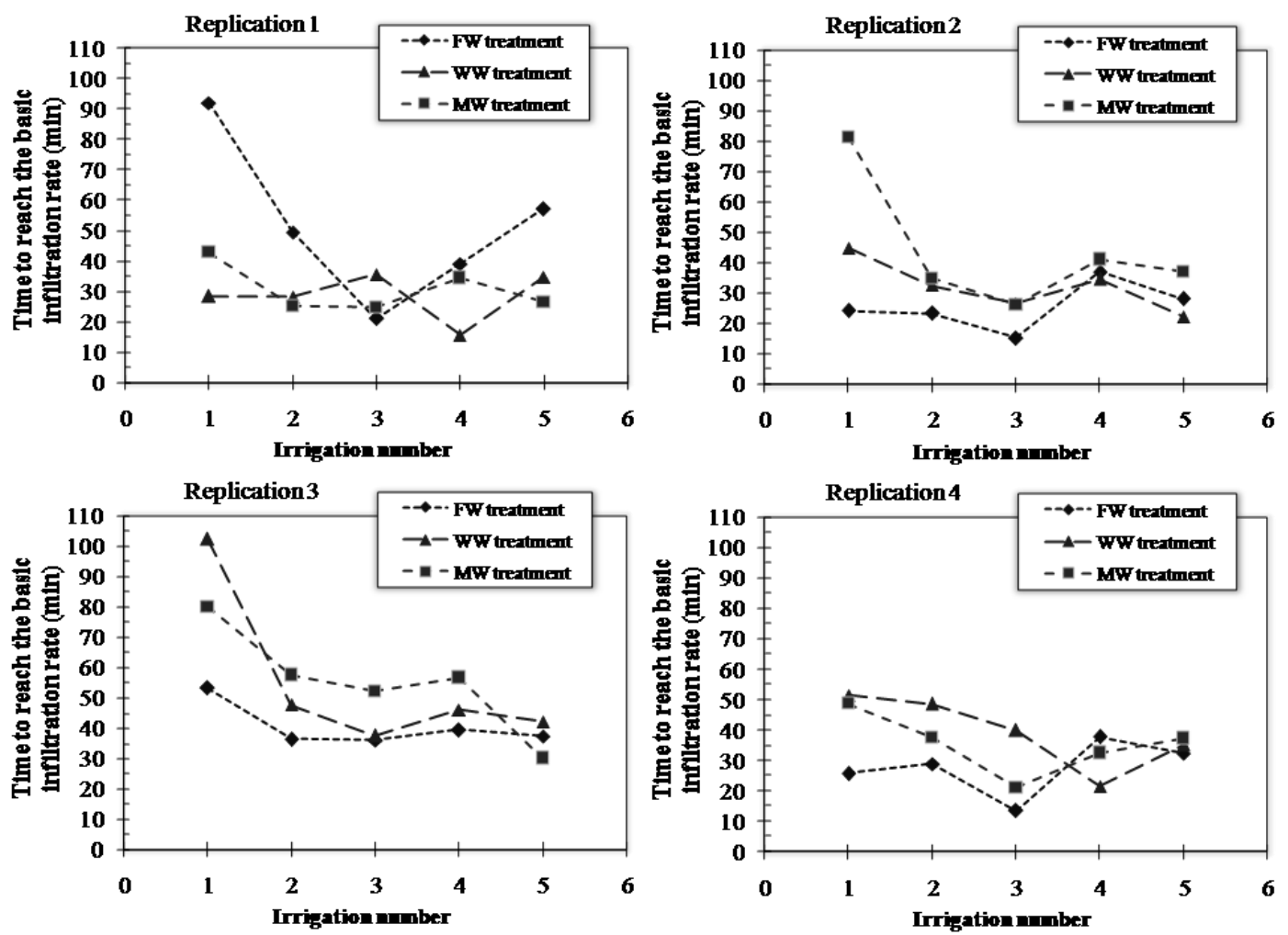

Fig7. Time to reach the basic infiltration rate after runoff beginning

About this parameter was understood a downtrend during the irrigations (Fig. 7). Water treatments did not cause significant difference between results (Table 7); but mentioned parameter for WW and MW is more than FW mostly.

Table7. Statistical analysis for storage time

\begin{tabular}{|c|c|c|c|c|c|c|c|}
\hline \multirow{2}{*}{ Change source } & \multirow{2}{*}{\multicolumn{2}{|c|}{ Free degree Significant level }} & \multirow[b]{2}{*}{ Treatment } & \multirow{2}{*}{$\begin{array}{l}\text { Mean values of } \\
\text { relative changes }\end{array}$} & \multicolumn{3}{|c|}{ Significant level } \\
\hline & & & & & FW & WW & MW \\
\hline Treatment & 2 & $25 \%$ & FW & $0.041 \mathrm{a}$ & $100 \%$ & $37 \%$ & $28 \%$ \\
\hline Replication & 3 & $43 \%$ & WW & $-0.200 \mathrm{a}$ & $37 \%$ & $100 \%$ & $69 \%$ \\
\hline Experimental error & 6 & - & MW & $-0.309 a$ & $28 \%$ & $69 \%$ & $100 \%$ \\
\hline
\end{tabular}

For this parameter in WW and MW treatments the regression equation is as following:

$T_{\text {str }}=35.553+2.213 T S S-1.398 C O D+0.161 N$

with $R^{2}$ of 0.10 , where $T_{s t r}=$ time to reach the basic infiltration rate after runoff beginning as min; $T S S$; COD; and $N$ as before. 
Also was found that magnetic field can be caused increasing of this parameter.

\subsection{Treatments Effects on Depletion Stage}

The time interval between the first observations in recession stage and cutoff time was measured (Fig. 8 ) to investigate of the treatments effect on depletion time.
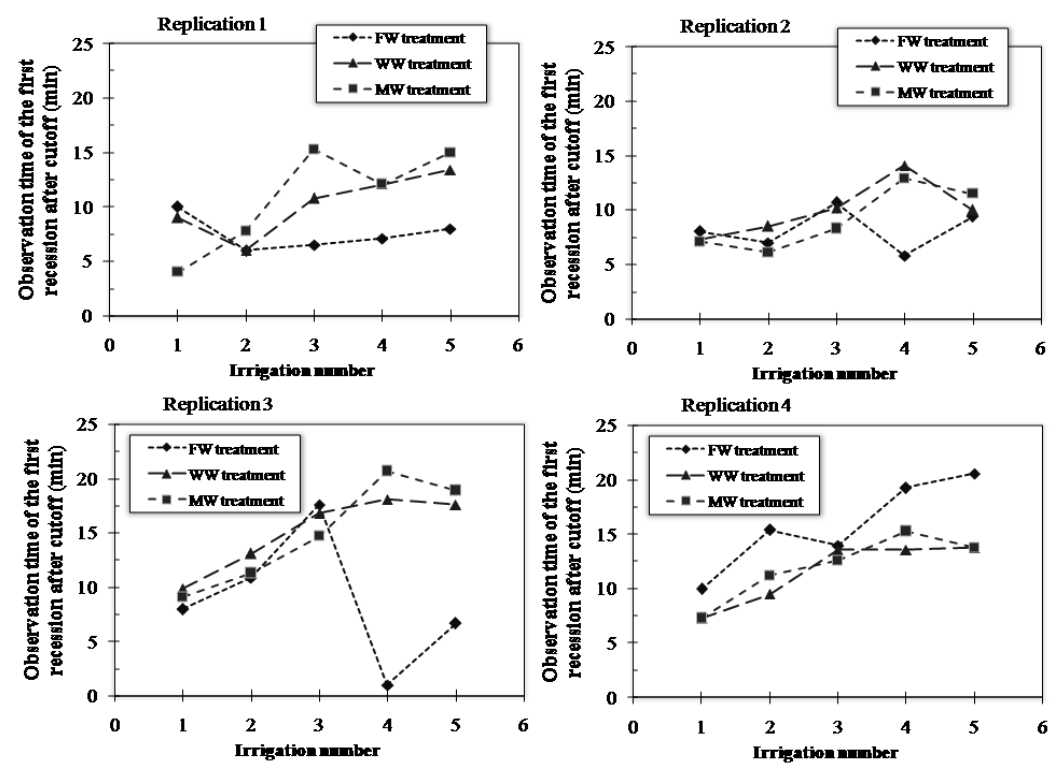

Fig8. Depletion time after cutoff

The increasing trend in depletion time was observed in all treatments (Fig. 8) that is caused by the common changes in soil structural during irrigations. Intensity of this trend is more for MW, WW and FW respectively.

Table8. Statistical analysis for depletion time

\begin{tabular}{lcclcccc}
\hline \multirow{2}{*}{ Change source } & \multirow{2}{*}{ Free degree Significant level } & & \multicolumn{2}{c}{ Mean values of } & \multicolumn{3}{c}{ Significant level } \\
\cline { 6 - 8 } & & & Treatment & relative changes & FW & WW & MW \\
\hline Treatment & 2 & $17 \%$ & FW & $-0.060 \mathrm{a}$ & $100 \%$ & $2 \%$ & $1 \%$ \\
Replication & 3 & $69 \%$ & WW & $0.630 \mathrm{a}$ & $2 \%$ & $100 \%$ & $26 \%$ \\
Experimental error & 6 & - & MW & $0.864 \mathrm{a}$ & $1 \%$ & $26 \%$ & $100 \%$ \\
\hline
\end{tabular}

For this parameter in WW and MW treatments the regression equation is as following:

$T_{d e p}=-9.437+0.409 T S S-0.115 C O D+2.316 N$

with a value for the coefficient of determination $R^{2}$ of 0.47 , where $T_{d e p}=$ depletion time as $\min ; T S S$, $C O D$, and $N$ as before.

Water treatments had also slightly effects, but there is a significant difference in depletion time values of WW and MW treatments than FW treatment at the 5\% (p < 0.05) level. These results in statistical analysis are in accordance with coefficient of determination $\left(R^{2}\right.$ of 0.47$)$ between wastewater quality parameters and depletion time.

\subsection{Treatments Effect on Recession Time}

Recession time was calculated as time interval between first and last recession observations in furrows for treatments (Fig. 9).

Table9. Statistical analysis for recession time

\begin{tabular}{|c|c|c|c|c|c|c|c|}
\hline \multirow{2}{*}{ Change source } & \multirow{2}{*}{\multicolumn{2}{|c|}{ Free degree Significant level }} & \multirow{2}{*}{ Treatment } & \multirow{2}{*}{$\begin{array}{l}\text { Mean values of } \\
\text { relative changes }\end{array}$} & \multicolumn{3}{|c|}{ Significant level } \\
\hline & & & & & FW & WW & MW \\
\hline Treatment & 2 & $69 \%$ & FW & $-0.018 \mathrm{a}$ & $100 \%$ & $19 \%$ & $33 \%$ \\
\hline Replication & 3 & $19 \%$ & WW & $0.312 \mathrm{a}$ & $19 \%$ & $100 \%$ & $55 \%$ \\
\hline Experimental error & 6 & - & MW & $0.184 \mathrm{a}$ & $33 \%$ & $55 \%$ & $100 \%$ \\
\hline
\end{tabular}



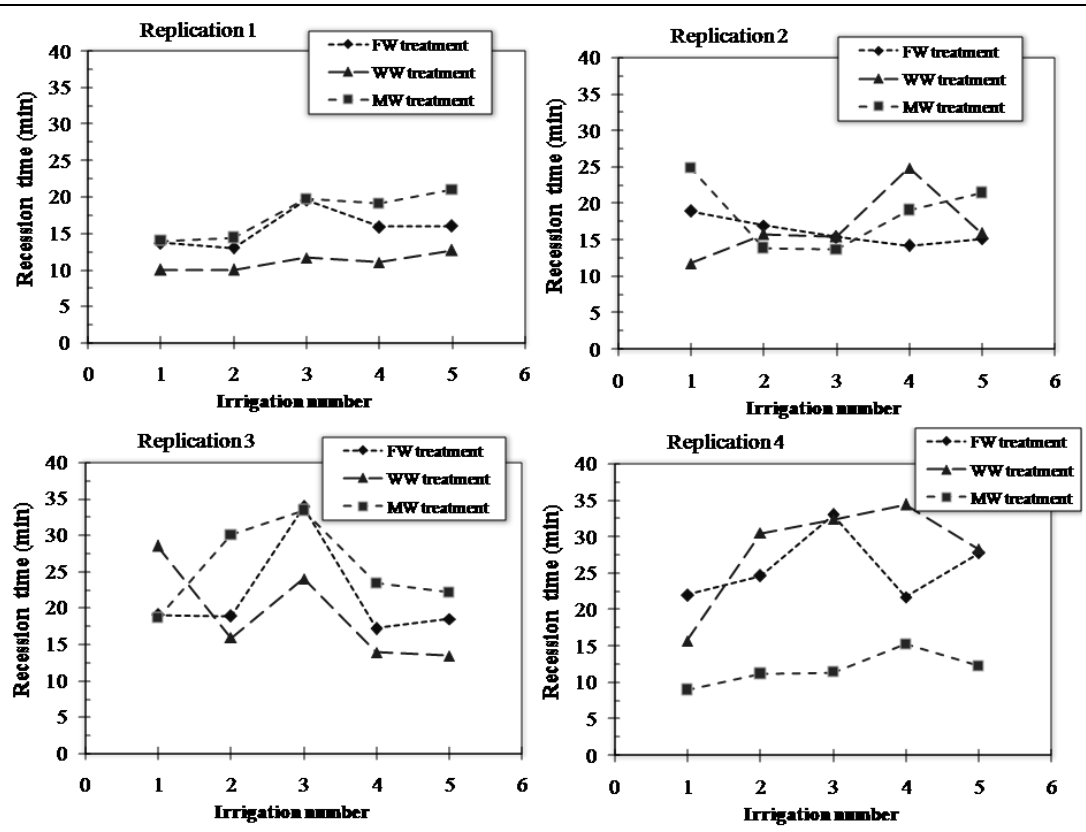

Fig9. Recession time graphs

Recession time in FW is more than WW and MW in $65 \%$ irrigations. This may be ascribed to the more basic infiltration rate for WW treatment that was caused recession time reduction in this treatment.

For this parameter in WW and MW treatments the regression equation is as following:

$T_{\text {rec }}=5.795-0.173 T S S+0.233 C O D+0.272 \mathrm{~N}$

with a value for the coefficient of determination $R^{2}$ of 0.03 (very poor), where $T_{\text {rec }}=$ recession time as $\min ;$ TSS, COD, and $N$ as before.

\section{CONCLusion}

In order to flow hydraulic investigation of the wastewater on the soil were practiced furrow irrigations with wastewater that the following results were obtained:

1. Magnetic field effect on WW quality was not significant, however electrical conductivity increased slightly.

2. In all treatments, the basic infiltration rate had downtrend during irrigation season. In most cases, MW had also highest values of basic infiltration rate and for WW was higher than FW.

3. A downtrend for mean infiltration rate in $0-30$ and 30-60 intervals was found during irrigations. Values of this parameter for WW and MW than FW are less and more in 0-30 and 30-60 intervals in more cases respectively.

4. Excluding duration of depletion phase, parameters of flow hydraulic of WW and MW on soil such as advance, recession and storage time had not difference significantly influenced by water quality treatments, but values of advance and storage time for WW and MW than FW were higher mostly.

5. According to regressions equation was found a negative correlation between " $f_{o}$ ", mean infiltration rate for $0-30 \mathrm{~min}$ and $30-60 \mathrm{~min}$ ranges and $T_{a d v}$ with TSS and irrigation number; and a positive correlation between these parameters with $C O D$.

6. Regression equations were showed a negative correlation between $T_{s t r}$ and $T_{d e p}$ with $C O D$; and a positive correlation between these parameters with TSS and irrigation number.

7. In parameter of $T_{\text {rec }}$, positive correlations are with irrigation number and $C O D$; and negative correlation is with TSS.

\section{ACKNOWLEDGEMENT}

The writers sincerely appreciate from water engineering, soil science and civil engineering departments, Isfahan University of Technology that helped us in this research. 


\section{REFERENCES}

[1] Bedbabis, S., B. B. Rouina, M. Boukhris and G. Ferrara. 2014. Effect of irrigation with treated wastewater on soil chemical properties and infiltration rate. J. Environ manage. 133: 4550.DOI:10.1016/j.jenvman.2013.11.007.

[2] Becerra-Castro, C., A. R. Lopes, I. Vaz-Moreira, E. F. Silva, C. M. Manaia, and O. C. Nunes. 2015. Wastewater reuse in irrigation: A microbiological perspective on implications in soil fertility and human and environmental health. Environ Int.75: 117-135. DOI: 10.1016/j.envint.2014.11.001.

[3] Muyen, Z., G. A. Moore, and R. J. Wrigley. 2011. Soil salinity and sodicity effects of wastewater irrigation in South East Australia. Agr. Water Manage. 99: 33-41. DOI: 10.1016/j.agwat.2011.07.021.

[4] Zema, D. A., G. Bombino, S. Andiloro, and S. M. Zimbone. 2012. Irrigation of energy crops with urban wastewater: Effects on biomass yields, soilsand heating values. Agr. Water Manage. 115: 55-65. DOI: 10.1016/j.agwat.2012.08.009.

[5] Jun-feng, W., W. Gen-xu, W. Hua. 2007. Treated wastewater irrigation effect on soil, crop and environment: Wastewater recycling in the loess area of China. J. Environ Sci. 19: 1093-1099. DOI: $10.1016 / \mathrm{S} 1001-0742(07) 60178-8$.

[6] Viviani, G., and M. Iovino. 2004. Wastewater reuse effects on soil hydraulic conductivity. $J$. Irrig. Drain Eng. 130 (6): 476-484. DOI: http://dx.doi.org/10.1061/(ASCE)07339437(2004)130:6(476).

[7] Arye, G., J. Tarchitzky, and Yona Chen. 2011. Treated wastewater effects on water repellency and soil hydraulic properties of soil aquifer treatment infiltration basins. J. Hydrol. 397: 136145. DOI: 10.1016/j.jhydrol.2010.11.046.

[8] Sou/Dakouré, M. Y., A. Mermoud, H. Yacouba, and P. Boivin. 2013. Impacts of irrigation with industrial treated wastewater on soil properties. Geoderma. 200-201: 31-39. DOI: 10.1016/j.geoderma.2013.02.008.

[9] Kincaid., D. C. 1986. Intake rate: border and furrow. American Society of Agronomy-Soil Science Society of America, Methods of Soil Analysis, Part I. Physical and Mineralogical Methods-Agronomy Monograph no. 9 (2nd Edition). 871-887.

[10] Ostad-Ali-Askari, K., Shayannejad, M. 2015, Study of sensitivity of Autumnal wheat to under irrigation in Shahrekord, Shahrekord City, Iran. International Journal of Agriculture and Crop Sciences, 8 (4), 602-605.

[11] Shayannejad, M., Akbari, N., Ostad-Ali-Askari, K. 2015, Study of modifications of the river physical specifications on muskingum coefficients, through employment of genetic algorithm. International Journal of Development Research, 5(3), 3782-3785.

[12] Ostad-Ali-Askari, K., Shayannejad, M. 2015, The Reviews of Einstein's Equation of Logarithmic Distribution Platform and the Process of Changes in the Speed Range of the Karkheh River, Khuzestan province, Iran. International Journal of Development Research, 5(3), 3786-3790.

[13] Ostad-Ali-Askari, K., Shayannejad, M., Ghorbanizadee-Kharazi, H. 2015, Assessment of artificial neural network performance and exponential regression in prediction of effective rainfall, International Journal of Development Research, 5(3),3791-3794.

[14] Shayannejad, M. Akbari, N. and Ostad-Ali-Askari, K. 2015, Determination of the nonlinear Muskingum model coefficients using genetic algorithm and numerical solution of the continuity. Int. J. of Science: Basic and Applied Research, 21(1),1-14.

[15] Ostad-Ali-Askari, K., Shayannejad, M. 2015, The Study of Mixture Design for Foam Bitumen and the Polymeric and Oil Materials Function in Loose Soils Consolidation. Journal of Civil Engineering Research, 5(2), 39-44. DOI: 10.5923/j.jce.20150502.04

[16] Sayedipour, M., Ostad-Ali-Askari, K., Shayannejad, M. 2015, Recovery of Run off of the Sewage Refinery, a Factor for Balancing the Isfahan-Borkhar Plain Water Table in Drought Crisis Situation in Isfahan Province-Iran. American Journal of Environmental Engineering, 5(2): 43-46. DOI: $10.5923 /$ j.ajee.20150502.02

[17] Ostad-Ali-Askari, K., Shayannejad, M. 2015, Developing an Optimal Design Model of Furrow Irrigation Based on the Minimum Cost and Maximum Irrigation Efficiency. International Bulletin of Water Resources \& Development, 3(2), 18-23. 
[18] Ostad-Ali-Askari, K., Shayannejad, M. 2015, Presenting a Mathematical Model for Estimating the Deep Percolation Due to Irrigation. International Journal of Hydraulic Engineering, 4(1), 17 21. DOI: $10.5923 /$ j.ijhe.20150401.03.

[19] Ostad-Ali-Askari, K., Shayannejad, M. 2015, Usage of rockfill dams in the HEC-RAS software for the purpose of controlling floods. American Journal of Fluid Dynamics, 5(1), 23-29. DOI: 10.5923/j.ajfd.20150501.03.

[20] Raeisi-Vanani, H., Soltani Todeshki, A. R., Ostad-Ali- Askari, K., Shayannejad, M. 2015, The effect of heterogeneity due to inappropriate tillage on water advance and recession in furrow irrigation. Journal of Agricultural Science, 7(6), 127-136.

[21] Soltani-Todeshki, A. R., Raeisi-Vanani, H., Shayannejad, M., Ostad-Ali-Askari, K. 2015, Effects of magnetized municipal effluent on some chemical properties of soil in furrow irrigation. International Journal of Agriculture and Crop Sciences, 8(3), 482-489.

[22] Ostad-Ali-Askari, K., Shayannejad, M. 2015, Optimal design of pressurized irrigation laterals installed on sloping land. International Journal of Agriculture and Crop Sciences, ISSN 2227670X. 8(5), 792-797.

[23] Ostad-Ali-Askari K, Shayannejad M, Eslamian S, Navab-Pour B. 2016, Comparison of solution of Saint-Venant equations by characteristics and finite difference methods for unsteady flow analyzing in open channel. International Journal of Hydrology Science and Technology, 6(3), 918.

[24] Ostad-Ali-Askari K, Shayannejad M, Eslamian S, et al. 2017, Deficit Irrigation: Optimization Models. Management of Drought and Water Scarcity. Handbook of Drought and Water Scarcity, Taylor \& Francis Publisher, USA. Vol. 3. 1th Edition, pp: 373-389.

[25] Eskandari S, Hoodaji M, Tahmourespour A, Abdollahi A, Mohammadian-Baghi T, Eslamian S, Ostad-Ali-Askari K. 2017, Bioremediation of Polycyclic Aromatic Hydrocarbons by Bacillus Licheniformis ATHE9 and Bacillus Mojavensis ATHE13 as Newly Strains Isolated from OilContaminated Soil. Journal of Geography, Environment and Earth Science International, 11(2): $1-11$.

[26] Raeisi Vanani H, Shayannejad M, Soltani Tudeshki A.R, Ostad-Ali-Askari K, Eslamian S, et al. 2017, Development of a new method for determination of infiltration coefficients in furrow irrigation with natural non-uniformity of slope. Sustain. Water Resour. Manag., 3(2): 163-169.

[27] Shojaei N, Shafaei-Bejestan M, Eslamian S, Marani-Barzani M, P. Singh V, Kazemi M, OstadAli-Askari K. 2017, Assessment of Drainage Slope on the Manning Coarseness Coefficient in Mountain Area. International Journal of Constructive Research in Civil Engineering (IJCRCE), 3(1): 33-40.

[28] Bahmanpour H, Awhadi S, Enjili J, Hosseini S.M, Raeisi Vanani H, Eslamian S, Ostad-AliAskari K. 2017, Optimizing Absorbent Bentonite and Evaluation of Contaminants Removal from Petrochemical Industries Wastewater. International Journal of Constructive Research in Civil Engineering (IJCRCE), 3(2): 34-42.

[29] Shayannejad M, Eslamian S, Gandomkar A, Marani-Barzani M, Amoushahi-Khouzani M, Majidifar Z, Rajaei-Rizi F, Kazemi M, P. Singh V, Dehghan SH, Shirvani-Dastgerdi H.R, Norouzi H, Ostad-Ali-Askari K. 2017, A Proper Way to Install Trapezoidal Flumes for Measurements in Furrow Irrigation Systems. International Journal of Research Studies in Agricultural Sciences (IJRSAS), 3(7): 1-5.

[30] Dehghan Sh, Kamaneh S.A.A., Eslamian S, Gandomkar A, Marani-Barzani M, AmoushahiKhouzani M, Singh V.P., Ostad-Ali-Askari K. 2017, Changes in Temperature and Precipitation with the Analysis of Geomorphic Basin Chaos in Shiraz, Iran. International Journal of Constructive Research in Civil Engineering (IJCRCE), 3(2): 50-57.

[31] Ostad-Ali-Askari K, Shayannejad M. 2016, FLOOD ROUTING IN RIVERS BY MUSKINGUM'S METHOD WITH NEW ADJUSTED COEFFICIENTS. International Water Technology Journal, IWTJ, 6(3): 189-194.

[32] Ostad-Ali-Askari K, Shayannejad M, Ghorbanizadeh-Kharazi H. 2017, Artificial Neural Network for Modeling Nitrate Pollution of Groundwater in Marginal Area of Zayandeh-rood River, Isfahan, Iran. KSCE Journal of Civil Engineering, 21(1):134-140. Korean Society of Civil Engineers. DOI 10.1007/s12205-016-0572-8. 
[33] Raeisi-Vanani H, Soltani-Toudeshki A.R, Shayannejad M, Ostad-Ali-Askari K, Ramesh A, Singh V.P., Eslamian S. 2017, Wastewater and Magnetized Wastewater Effects on Soil Erosion in Furrow Irrigation. International Journal of Research Studies in Agricultural Sciences (IJRSAS), 3(8): 1-14. http://dx.doi.org/10.20431/2454-6224.0308001.

[34] Raeisi-Vanani H, Shayannejad M, Soltani-Toudeshki A.R, Arab M.A, Eslamian S, AmoushahiKhouzani M, Marani-Barzani M, Ostad-Ali-Askari K. 2017, A Simple Method for Land Grading Computations and its Comparison with Genetic Algorithm (GA) Method. International Journal of Research Studies in Agricultural Sciences (IJRSAS), 3(8): 26-38.

[35] Crusberg, T. C., and Eslamian, S., 2015, Choosing Indicators of Fecal Pollution for Wastewater Reuse Opportunities, Urban Water Reuse Handbook, Ch. 42, Ed. By Eslamian, S., Taylor and Francis, CRC Group, 511-520.

[36] Boogaard, F. and Eslamian, S, 2015, Wastewater Monitoring, Urban Water Reuse Handbook, Ch. 48, Ed. By Eslamian, S., Taylor and Francis, CRC Group, 583-586.

[37] Saket, R. K. and Eslamian, S., 2015, Use of Wastewater for Hydroelectric Power Generation, Urban Water Reuse Handbook, Ch. 63, Ed. By Eslamian, S., Taylor and Francis, CRC Group, 827-838.

[38] Hamdy, A. and Eslamian, S., 2015, Sustainable Reuse and Recycling of Treated Urban Wastewater, Urban Water Reuse Handbook, Ch. 80, Ed. By Eslamian, S., Taylor and Francis, CRC Group, 1039-1054.

[39] Abedi-koupai, J., Mollaei, R., Eslamian, S. S., 2015, The effect of pumice on reduction of cadmium uptake by spinach irrigated with wastewater, Ecohydrology and Hydrobiology, Vol. 15, No. 4, 208-214.

[40] Fazlolahi, H. and S. S. Eslamian, 2014, Using wetland plants in nutrient removal from municipal wastewater, Int. J. Hydrology Science and Technology, Vol. 4, No. 1, 68-80.

[41] Fazlolahi, H. and S. S. Eslamian, 2013, Nitrogen and Phosphorus removal from municipal wastewater by three wetland plant species, Journal of River Engineering, Vol. 1, No. 2., 14-20.

[42] Amiri, M. J., Abedi-Koupai, J., Eslamian, S., Mousavi, S. F. and Arshadi, M., 2013, Modelling $\mathrm{Pb}$ (II) adsorption based on synthetic and industrial wastewaters by ostrich bone char using artificial neural network and multivariate non-linear regression, Int. J. Hydrology Science and Technology, Vol. 3, No. 3, 221-240.

[43] Amininejad, S. M., Eslamian, S. S., Amininezhad, S. M., 2013, Photocatalytic Degradation of Model Textile Dyes in Wastewater Using ZnO Nanoparticles, 5th International Conference of Water Resources and Sustainable Development, 24-25 February, Algiers.

[44] Amininejad, S. M., Eslamian, S. S., Amininezhad, S. M., 2013, Application of ZnO Nanoparticles in Wastewater Disinfection, 5th International conference of Water Resources and Sustainable Development, 24-25 February, Algiers.

[45] Eslamian, S. S., Okhravi, S. S., Fazlolahi, H. and Eslamian, F. 2012. Sustainable Management of Water Resources with Techniques of Rainwater Harvesting In Ancient and Present, IWA Specialized Conference on Water \& Wastewater, Istanbul-Turkey.

[46] Eslamian, S. and Tarkesh-Isfahani, S., 2010. Evaluating the most efficient irrigation systems in wastewater reuse, Pakistan Agriculture: Challenges and Opportunities, Kashmir, Pakistan.

[47] Mousavi, S. Z., Eslamian, S. S., Sharifani, M., 2010, Increasing Berhi Date Palm's Yield and Cost Efficiency, as Irrigated by Reclaimed Sewage Wastewater, Pakistan Agriculture: Challenges and Opportunities, Kashmir, Pakistan

[48] Eslamian, S. S., Tarkesh-Isfahany, S., 2011, Industrial reuse of urban wastewaters, a step towards sustainable development of water resources, 1st International Conference on Desalination and Environment: A Water Summit, 29 Oct. 1 Nov., Beach Rotana, Abu Dhabi, UAE.

[49] Eslamian, S., Tarkesh-Isfahani, S., Malekpour, I., 2010, Investigating heavy metals concentration of a wastewater treatment plant for agricultural and landscape reuses, Dryland Hydrology: Global Challenges Local Solutions, September 1-4, Westin La Paloma-Tucson, USA.

[50] Abedi-Koupai, J., Eslamian, S. S. and Fakouri, F., 2010, The Effects of Applying Treated Wastewater on the Physical and Mechanical Behavior of Soil-Root Interactions, Geophysical Research Abstracts, Vol. 12, EGU2010-13610, EGU General Assembly, Vienna, Austria. 
[51] Eslamian, S. S., Hedayat, E. and S. Tarkesh Esfahani, 2009, Reusing Reclaimed Wastewater through Artificial Recharge for Increasing Sustainable Water, First Conference of Water Resources Management, Shahroud, Iran.

[52] Chavoshi, S. and S. Eslamian, 2001, The role of traditional utilization of water in management of water resources of arid land, Second Regional Conference on Water and Wastewater Management in Asia, Tehran, Iran.

[53] Abedi-Koupai, J., Ghaheri, E., Eslamian, S.S. and Hosseini, H., 2013, Investigation the Kinetic Models of Biological Removal of Petroleum Contaminated Soil around Oil Pipeline Using Ryegrass, Water and Wastewater, Vol. 89, No. 1, 62-68.

[54] Eslamian, S. S., Modarres, R. and S. Soltani, 2006, Spatial Grouping of Drought Using Standardized Precipitation Index in Isfahan Province, Water and Wastewater Journal, No. 57, 7275.

[55] Feyzi, H. and S. S. Eslamian, 2005, Comparing regional and at-site L-moments for estimation of maximum monthly rainfall in the Zayandehroud basin, Water and Wastewater Journal, Vol. 53, $1-13$.

[56] Chavoshi-Boroujeni, S. and S. Eslamian, 1999, Regional Flood Analysis in Arid Zones Using Hybrid Method, Water and Wastewater Journal, Vol. 30: 23-35.

[57] Eslamian, S. S. and K. Farzamnia, 1999, Regionalization of Flood Frequency Estimation using Cluster Analysis, Water and Wastewater Journal, Vol. 31: 1-12.

[58] Mohieyimen P, Eslamian S, Ostad-Ali-Askari K, Soltani M. 2017,Climate Variability: Integration of Renewable Energy into Present and Future Energy Systems in Designing Residential Buildings. International journal of Rural Development, Environment and Health Research (IJREH), 1(2): 18-30.

Citation: Dr. Kaveh Ostad-Ali-Askari et al. (2017). Flow Hydraulic Investigation of the Wastewater on the Soil and Magnetic Field Effects in This Field, International Journal of Constructive Research in Civil Engineering, 3(3), pp.1-15.

Copyright: () 2017 Dr. Kaveh Ostad-Ali-Askari, et al. This is an open-access article distributed under the terms of the Creative Commons Attribution License, which permits unrestricted use, distribution, and reproduction in any medium, provided the original author and source are credited 